\author{
Nadia Hannawi" \\ Al-Mustansiriya University, Iraq, Baghdad, \\ *e-mail: -nada2007hk@yahoo.com
}

\title{
THE MANIFESTATIONS OF THE VOLITION PHILOSOPHY IN THE MIND OF AL-FARABI
}

This research revolves around the philosophy of will that Paul Ricour has been looking at. The focus of this philosophy is the human error, which is based on a number of concepts, including five: infallibility and incongruity, mixture and mediator, the idea of the universal, the impact of misery, infinity Dozens of books and hundreds of studies and research papers have been written in Al-Farabi's philosophical legacy, and various methodologies and ideological, sociological, anthropological and political propositions have been formulated around it, and theories have been developed in it, some of which are literary and intellectual and others are psychological, social and cultura .Each of these concepts is based on intellectual constructs and procedural representations that deal with issues of thought and existence. This research attempts to reconcile these five concepts and the ideas of the philosopher Abu Nasr al-Farabi (339 e) by shedding light on some of his books and letters.

Key words: Concept, Al-Farabi, Philosophy, Ricor, volition.

$$
\begin{gathered}
\text { Надия Ханнауи* } \\
\text { Ә^-Мустансирия университеті, Ирак, Багдад қ. } \\
\text { *e-mail: -nada2007hk@уаһоo.com } \\
\text { Әл-Фарабидің көзқарастарындағы ерік философиясының көріністері }
\end{gathered}
$$

\section{Ә^-Фарабидің көзқарастарындағы ерік фимософиясының көріністері}

Бұл зерттеуде Поль Рикёр қарастырған ерік философиясы айқындалып көрсетіледі. Бұл философияның назарында адамның бұрыс ойлауы негізінде жатқан бірқатар тұжырымдамалар, соның ішінде мына бесеуі кіретіні белгілі: жаңылмастық пен жеткіліксіздік, шатасу мен делдалдық, әмбебап илея, азаптың әсері және шексіздік. Әл-Фарабидің философияяық мұрасы негізінде ондаған кітаптар мен жүздеген зерттеулер мен ғылыми еңбектер жазылды және оның айналасында әртүрлі әдістемелер, идеологиялық, социологиялық, антропологиялық, және саяси ұстанымдар тұжырымдалды, сонымен қатар теориялар жасалды, олардың кейбіреулері әдебиинтелмектуалды және басқа психологиялық, әлеуметтік және мәдени болып табылады. Біз ерік философиясының әр тұжырымдамасына, оның зияткерлік сипаттамаларына, терминологиялық, Аетерминанттарына және Пол Рикер өзінің кітабында түсіндірген практикалық ерекшеліктеріне (ерік философиясы, қате адам), сондай-ақ Әбу Насыр әл-Фарабидің әртүрлі ой салаларындағы көптігі мен әртүрлілігі туралы жинақтарында не бар екеніне тоқталып айқындаймыз. Бұл тұжырымламалардың әрқайсысы ойлау мен болмыс мәселелерін қарастыратын интелмектуалды құрылымдар мен үлерістік ойларға негізделген. Бұл зерттеуде автор философ Әбу Насыр әлФарабидің бес концепциясы мен жазбаларын бөлектеу арқылы осы бес тұжырымдамалары мен идеяларды үйлестіріп көрсетуге тырысады.

Түйін сөздер: тұжырымдама, әл-Фараби, философия, Рикер, ерік.

\author{
Надия Ханнауи \\ Университет А^ь-Мустансирия, Ирак, г. БагАаА, \\ *e-mail: -nada2007hk@yahoo.com
}

\section{Проявления фикософии воли во взгяядах аль-Фараби}

В данном исследовании рассматривается философия воли, которую изучал Поль Рикер. В центре внимания этой философии - человеческое заблуждение, в основе которого лежит ряА концепций, включая пять из них: непогрешимость и несоответствие, смешение и посредничество, идея всеобщего, влияние страдания и бесконечность. Аесятки книг и сотни исследовательских работ были написаны на основе философского наследия АльФараби, были сформулированы различные методологии, идеологические, социологические, антропологические и политические положения, а также были разработаны теории, некоторые из которых литературно-интемлектуальные и лругие психологические, социальные и культурные. Мы остановимся на каждой концепции философии воли, ее интелмектуальных характеристиках, 
ее терминологических детерминантах и практических особенностях, которые Поль Рикер объяснил в своей книге (Философия воли, Человек по ошибке), а также на том, что содержится в сборниках Абу Насра аль-Фараби о множественности и разнообразии в различных областях мысли. Каждая из этих концепций основана на интелмектуальных конструкциях и процессуальных представлениях, которые касаются вопросов мысли и существования. В данном исследовании принимаются попытки согласования пяти концепций и идей философа Абу Насра а^ь-Фараби, взятых из его книг и писем.

Кмючевые слова: концепция, аль-Фараби, философия, Рикер, воля.

\section{Introduction}

Many philosophers are the Greek, Stoics, Sophists, then Egyptians, Babylonians, Buddhists, Hindus, Chinese, and Zoroastrians, but what is important is what came to us from the products of the philosophers Plato and Aristotle, who had the greatest impact in pushing human thought forward. As for the first, he looked towards a city he wanted to be happy, leading to a life of peace and beauty, while the second philosopher gave attention to reason, logic, art and poetry, setting the rules of the human mind.

In spite of their great influence in affirming the mind and the act of imagination about nature, philosophy after them has aged until it almost perished and died, but it was transferred from the Greek language to the Syriac language and from there to the Arabic language during the third century of migration. Muslim philosophers have added many concepts and conventions to it, enhancing it with Islamic visions and perceptions.

One of those who contributed to that development is Abu Nasr Al-Farabi, who, by coincidence, wanted to be a student of Matthew Ibn Yunus, who was the first to translate the Greek heritage from Syriac into Arabic, which made Al-Farabi possessing a knowledge that would later qualify him to be one of the poles of Islamic philosophy. The title (the second teacher) because of his deep imbibition of the philosophies of Plato and Aristotle, so he left behind him an important achievement of books, letters, explanations and commentaries on various issues of logic, nature, syntax, music, politics, ethics, astronomy, engineering, astrology, medicine, etc., as part of the Arab-Islamic philosophical heritage, which will leave an important impact on Medieval thinkers and philosophers, thinkers of the Renaissance and those who will follow them in later ages.

Dozens of books and hundreds of studies and research papers have been written in Al-Farabi>s philosophical legacy, and various methodologies and ideological, sociological, anthropological and political propositions have been formulated around it, and theories have been developed in it, some of which are literary and intellectual and others are psychological, social and cultural.

Despite the importance of Al-Farabi>s intellectual heritage; Some Western thinkers interested in eastern philosophy do not refer to it except from afar and may not refer to it at all, neglecting to mention it. Perhaps the reason is that the Westerners view Muslim philosophers as mere transmitters of Greek philosophy, and that their merit was specific in bringing this philosophy to the Renaissance, then Europe revived it. Again, as if the Muslim philosophers did not add a new Greek heritage, nor were they innovators and developers.

\section{Justification of the choice of article and goals} and objectives

Objectivity requires that thinkers and scholars, regardless of Western or Eastern, deal with philosophical history on a scale in which one side does not dominate the other. In this way, they will arrive at results of interest to humanity based on understandable reasons for what has been invented and determined. As for the issue of different thinking in looking at the eastern philosopher as a wise old man who thinks in the way of the image, and looking at the Western philosopher as a thinker who creates concepts, it is not accurate at all, and the reason is that the concept remains the philosopher's demand, and philosophy remains the field of knowledge based on the creation of concepts ..

This is how we found the concept of temus, the concept of the nous or the type in Plato, the catharsis and the essence in Aristotle, the races, the predicate, and the essence in Al-Farabi, just as we found the cogito in Descartes, the monad in Leibitz, the permanence of Bergson, the strength of Schling, the supreme man in Frederick Nietzsche..and other Intellectual concepts and theoretical suggestions.

\section{Scientific research methodology}

General scientific methods, such as analysis, analytical analysis were used during the writing of the article. Materials related to the research topic were collected, processed and structural analysis of foreign authors' works was carried out. 
Al-Farabi was born in the year 259 or $260 \mathrm{AH}$ - $870 \mathrm{CE}$ and died in the year 339-950 CE, he is the most famous philosophers of the East in general and Muslim philosophers in particular, and because of his love for knowledge he cut the deserts and across the seas small, intending to Baghdad to seek knowledge in the third century of migration until he reached it, so he learned the Arabic language and worked with the sciences of wisdom. In Bagh$\mathrm{dad}$, he found professors from whom he learned the origins of knowledge, studied logic, and understood him in language, grammar, and morphology at the hands of the file in front of the linguists of Basrah.

Thus Al-Farabi built his own philosophical mind to be the second teacher after the first teacher Aristotle. Perhaps the reason for his name comes from that he was the first philosopher who combined the three elements: the Aristotelian, Platonic and Islamic element, or because he was able to explain Aristotle>s complex book (Post-Nature), able to reconcile Greek philosophy with Islamic issues such as the issue of prophet hood, judgment, destiny, the problem of existence and the creation of the world and man in life .

In order to encompass Al-Farabi>s legacy, and its theoretical concepts and philosophical issues; We will deal with this heritage from an approach that explores the concepts of (Philosophy of volition) that the French thinker Paul Ricour theorized, by benefiting from the manifestations of the philosophical achievement and its dimensions, which were included in the books of Abu Nasr Al-Farabi and his many letters.

\section{Results and discussion}

Manifestations of the concepts of the philosophy of the volition /

It is known that concepts in philosophy are not given but created, and "the concept presents itself within itself as a self-proposition, and the two matters creativity and self-discourse are identical as long as everything that is actually creative... is characterized by that by a self-proposition of itself or by a self-eloquent feature by which we recognize it (Deleuze, Gil, and Guitari, Flex, 1997: 81). This is what Al-Farabi clarified, stressing that "the boundary that was said in philosophy is knowledge of things as they are, a correct boundary that indicates the same limitation and indicates what it is."(1)

However, this term in modern philosophy has turned into what has been called (flat) which is The absolute ground of philosophy, or the foundation from which concepts originate, that began with Plato, where every philosopher paints a new plane of immanence that is a substance for being and thought.
If the surfaces must be acclimatized; Islam will be the acclimatization of philosophy subjects during the Middle Ages. Paul Ricoeur was very interested in Plators philosophy in (The Republic). He paused at the happy city and preoccupied himself with the human soul, which for him is a field of power, subjected to the double attraction of reason, metaphor, analogy, symbolism and ideal. And because through the soul we work, learn, get angry, and desire, then the soul which is the third term which Plato (Timos) calls it becomes a mystery (Paul Ricoeur, 2008: 27).

It is known that knowledge as a theory takes precedence over the volition as a philosophy, and many philosophers have dealt with the theory of knowledge, presenting various propositions. From these influences and extensions arose Ricoeur's philosophy of the volition, who determined its formulas, explained its branches, classified its forms, and represented its positions which are based on different intellectual pillars with special concepts and specific manifestations.

That the moral vision of the world has its effect on going thinking as far as possible in this direction and Ricoeurs inference on this philosophy has been systematically based on specific concepts and specific conventions that include the theoretical and procedural dimensions; Based on the fact that constructing any concept requires a pure philosophical taste that may work with violence and may work with insinuation, forming within the language a language of philosophy, and the concept is not just a vocabulary dictionary; Rather, it is a context that amounts to a sublime or aesthetic level.

We will stop at each of the concepts of the philosophy of the volition, its intellectual characteristics, its terminological determinants, and its practical features that Paul Ricoeur explained in his book (Philosophy of the volition, the Mistakenly Man) and what is in the compilations of Abi Nasr Al-Farabi of the multiplicity and diversity in different fields of thought. The aim behind this diagnosis and that representation is to demonstrate the convergence of the collective intellectual natures that fall under the (Philosophy of volition) as one of the chapters of contemporary human philosophical thought, as follows:

Infallibility and Inappropriateness / It is an idea that believes that man is inclined to evil, and that he is prepared to fall into error or sin. I am astonished when I make a mistake. "If Plato had put the riddle of the soul in (the Temos), which is the transition from the Pius to the Logos, that is, from life to the mind; Paul Ricoeur sees in the soul the fragility of the emotion in which the fragility of 
consciousness and the fragility of the self, and that in the heart the moment of weakness is embodied, and then the possibility of error becomes possible, in the sense that the weakness of the human being is what makes evil possible, but the fragility of the mediation that the person conducts in the matter, not It prevents him from being "capable of both things: right and wrong, good and bad, the beautiful and the ugly." (Ricoeur, 2008:27).

And while explaining to us the secret of man in his being a mistake, and that "the possibility of moral evil is inscribed in the formation of man, the concept of infallibility will lead us to the limitations of creatures as a non-being. In these two matters lies the disproportion between being and nothing. Ricoeur does not hesitate to assert that disproportion and misery are what make the stakes in the philosophy of feeling based on the difference between the pure and transcendent interpretation of proportionality and the lived experience of misery, stressing that the two issues are interconnected: the issue of method and content, and the issue of incompatibility of the philosophy of feeling with the completion of meditation, stressing the need to solve these two issues together.It seems that the irreconcilable and the disproportionate have their presence in AlFarabi>s thought, in terms of his belief that in his statements man has a will at times and without volition at other times, and on that he says: Whatever the volition of man was considered by civil science. And what was of it, not from the will of man, was considered by natural science. "However, Al-Farabi denied the error to the sages of the Greeks, to be one of those who believed that the great sages of the Greeks were almost impossible to contradict what they say .. Because of his good belief in Greek philosophy ... Philosophy entered into on the basis of combining philosophical opinions and conciliation with what appeared to be different from them with some or with Islam. We do not find a contradiction in this matter, based on the fact that al-Farabi>s belief that "if different minds agree after contemplating them, training, searching, pitting, stubbornness, crying and stirring up opposite places, nothing is healthier than what I believed, witnessed and agreed upon." (Albert Nasri Nader, 1986: 110).

Because of this trust, philosophy became wisdom among Muslims, and Plato and Aristotle became wise and virtuous, and on the authority of them Al-Farabi said in the conclusion of one of his books: "Whoever contemplates what we have mentioned of the sayings of these two wise men ... this is enriching him from following the corrupt suspicions and illusions entered and gaining the burden of what is attributed to these virtues. From what they are innocent and from him separately (2)"

Al-Farabi often emphasizes the importance of the human will in separating mentally rather than sensibly between nomenclatures, genres, and sayings, and puts all of this under the name of (the science of teachings), whose function is to "look at the types of what is quantum. All the statements after he strikes them in his mind and concludes them from all the things that are attached to them and exposes them to them, whether those are from the will of the person or not from his will (Albert Nasri Nader, 1986: 82). This mental programming of the will in the form of the science of teaching exempts man from error and protects him from error. Spinoza will later define it as the method, assuming that the correct approach (Spinoza, 1990: 38-39) is the method that shows how we should direct our thought according to the principle of the correct idea first, and lastly how the orientation of thought is based on According to the criterion of inference by which we prove the correctness of that idea.

This will be confirmed by Frederick Hegel who does not see the truth, a coin struck that one can hand over ready as long as there is more lies than evil. There is no doubt that evil and lies are nothing but universals, but he believes in the statement that there is some truth in every lie, as both are true as oil and water that do not mix and are connected only from an external aspect . The facts, according to Hegel, are types of historical ones, which are "not innocent from the movement of self-awareness, and in order for one to know one of them, a lot of comparison and reference is required to books also, or whatever the matter should be traced back to research" (Frederick Hegel, 2006: 144-145 ). Thus infallibility is evidence of a person's weakness when evil overcomes him, and evidence of his disproportionate strength when good overcomes evil in him.

2) The mixture and the mediator / two concepts that arise from infallibility and disproportion, and if in Plato the mixture is a myth and the mediator for him is the mixture, then according to Paul Ricoeur they include an implicit understanding of the model of the right opinion, and on that he said: But they are limited to the influential style. ${ }^{(3)}$ )

Ricoeur spoke of the homogeneous medium, which is the same time which has now become the series of the pure image for all the volumes included in the sensed, in which the method of scattering and expansion is, and with the reasonable in which the condition of intuition becomes, (the chain) becomes the marvel of time. 
Acknowledgment of moderation means the existence of a law of division, such as dividing things into classes, races into types, and so on, Ricoeur says: "If a person is mediating between existence and nothingness, then he first mediates things. From the myth of the mixture ... in the philosophical discourse ".. The issue of division into types has occupied an important place for Al-Farabi, on the grounds that "science is a science for the known and the known is known to science, and the types of knowledge have no name in terms of their types of addition of which knowledge is their gender to the types of information that is their genres, such as grammar and rhetoric" (Mohsen Mahdi 1990: 87).

Because of that, it is not possible to say (grammar towards something is known by grammar); Rather, if we wanted to add grammar to something that has an addition of information to it in terms of grammar, we took it described by its gender, so we said, "Grammar teaches the thing about which it is known (Muhammad Salim Salem 1976: 26).

The attributes of a thing are gradual, so the more specific of it is called a kind, and the more general is called genre, and things are also divided into tangible, tangible, and imperceptible have an effect. From fire, steam, etc., then the stone and metal bodies on the surface and depth of the earth, then plants, non-speaking animals, and talking animals.

In saying in the conditions in which there are periodic movements and the common nature of the planets, Al-Farabi found that they sometimes close to some of what is beneath them, sometimes away from it, appearing sometimes and concealing sometimes, and these opposites catch them neither in their characteristics nor in the symptoms that approach them. It is in its proportions. And that is like rising and sunset, because they are relative to what underneath them are contradictory, and things are based on succession, stubbornness and contradiction, and it happens about their additions that are repeated and things that re-exist and return some in a shorter period and some in a longer period and on what is not repeated of their additions and conditions. Rather, it occurs at some point in time without being in the forefront.

Perhaps this is what is represented in photography, where things are embodied repeatedly returning as an industry that reproduces the natural with industrial production.

Poetry is an industry that is done by borrowing and permitting, and asking about it is done through it. The artifacts are five, and the question in each industry has its own style, type and place, and it is controversial, "Philosophy is a demonstrative ques- tion, and in debate a controversial question, and in sophistry a question of a sophist, and in rhetoric a rhetorical question, and in poetry a poetic question".

Ricoeurss concept of the homogeneous medium is represented by Al-Farabi in the determinations of the moral virtues, which are placed in dual or triple formulas. For example, the virtue of knowledge is not realized. Except for one of three: As for the honor of the subject, as for the investigation of the evidence, and as for the greatness of feasibility (Jaafar Al Yassin 1987: 48). It is known that the concept of a homogeneous mediator was widely represented in Plato's philosophy, and most of his concepts are defined by an understanding that has two or three components, and this understanding has also been embodied in modern philosophy. Being, or equal to Being, or inferior to Being, but the One higher above the Being, the equal of Being.

3) The idea of holisticism / Ricoeur was very interested in wholeness, which for him is an obsession that contradicts the (transcendent thinking) of human reality, and transcendent thinking is what makes holism a philosophical issue. Wholeness is moving towards the theory of the volition, so it is against (the pure). The holisticism that each of us forms does not become a problem except for a philosophy that is separated from it by asking another question, and by giving another focal point to the subjectivity, holism becomes a philosophical problem surprising as it is the distance between difference and the rest. What is combined excludes and what includes is not included Holisticism combines pre-philosophy or non-philosophy with what follows: "Philosophy does not begin anything at all; rather, it is based on non-philosophy that it lives from the substance of what was previously understood without thinking", and what is before philosophy is myth.

This is what Plato had alerted to, and on that, Ricoeur says: "Evil was not confused with physical existence, and that in Platonism there is an evil with injustice, and it is an evil specific to the soul." Ricoeur links the holistic with the ideas of happiness and destiny, and that when a person seeks wholeness of meaning, his desire is directed towards happiness as a holistic meaning and acceptance. As for Al-Farabi, The ultimate happiness in the afterlife is of four races: theoretical virtues, intellectual virtues, moral virtues, and practical industries. Theoretical virtues are the sciences whose ultimate purpose is to obtain assets and which they contain are reasonable and certain. These sciences include what happens to a person from the beginning of his life, in terms of how he does not feel and does not know how and where they occurred. 
Perhaps the most important representations of holisticism for Al-Farabi, is reflected in the letters that mean, for him, the science of certainty proofs, which is the science of science or the mother of science. This knowledge is as it is said: it was with the Chaldeans, who are the people of Iraq, then it became to the people of Egypt, then it passed to the Greeks, and it remained until it passed to the Syrians and then to the Arabs. The phrase about all that that science contained was in the Greek tongue, then it became in the Syriac tongue and then in the Arabic tongue. The Greeks called this knowledge wisdom. They call the possessor of her a philosopher, and they mean by him the lover and the influential of the greatest wisdom.

The book (Al-letters) is considered «the first comprehensive book published by Al-Farabi in the science of post-nature», and it is known that the word (letters) in the third and fourth centuries was a formulated word for several sciences that search for its nature and properties, that is, ideas, controversy, philosophy, engraving, tools and letters Meanings. According to Al-Farabi, the letters are a strategy or a protocol and a program for the philosophical debate and the rule from which the words and statements and then the articles are launched, and it is the basis of the question that is the basis of philosophy, thinking and the origin of language. This is also confirmed by modern philosophy. All doubt .Al-Farabi would not have delved into this science without the debate of the Seraphian, in which grammar triumphed over logic, so al-Farabi emerged victorious for logic, so he composed this book, answering questions about expressions and sayings, combining logic with language, and interpreting Aristotle>s book (After Nature).

His interest in the question and the sayings stems from the holistic understanding of the letters, and begins with the letter (that) meaning "persistence, permanence, perfection and trustworthiness in existence and knowledge of something.» If the first is fully existent, it cannot be that existence for something other than it, then if it is singular existence alone then it is one from this side. 〈

He discussed the issue of requiring the word boundary to be indicative of time, meaning that time does not depart from the word at all, because many people think that each name also indicates a time, as everything was for them in a time, such as: human and animal, so that things that if you understand their meanings would not leave them. Time is a necessity combined with it in the mind, and the word, with its connotation of the meaning of time, indicates its subject without a declaration, and the derivative nouns participate in that.
And that what gives permanent assets is their change and impermanence, "so in order to fulfill justice in these assets, one thing was not always kept as one by number, so its survival for the whole age was made as one by type. It needs to remain one by type until there are persons of that kind for a period of time. What then is destroyed and replaced by other people of that kind, and that is always on this example. "] [It is not hearing and speech that define a living organism in terms of living," because saying and pronouncing is not the distinction which is the utterance and you see many beasts that are not told while they are alive.

According to this vision, holisticism becomes a function with respect to the whole group of subjects that form its extension, and every complete concept is a sum in this sense and has a specific number. The topics of the concept are the elements of the group, which makes the holistic as a concept the backbone, while the parts are contiguous surfaces, and in this way the whole corresponds to the parts precisely, and nothing prevents the concepts from becoming one or becoming general faculties and losing their specificity, but also the flat may lose its openness.

4) The effect of misery / a concept that has a place in the philosophy of the volition, since it is he who gives "philosophy a material to contemplate, but not its starting point, so how do we move from the myth of the mixture from the rhetoric of misery to the philosophical discourse from the mitos to the logos". Ricoeur sees misery as the womb of every philosophy that is made out of incompatibility with regard to human ontology.

Ricoeur attributes both Phaedrus and the myths of the banquet and the republic to pre-influential misery, asserting that "the myth is the misery of philosophy, and every philosophy when it wants to talk about man is a philosophy of misery. This is really the condition of the miserable soul itself .

Karl Marx had dealt with the philosophy of misery, not with the premise that it is misery. Rather, from an economic standpoint, he sees that every economic saying has two bad and good sides. Napoleon was a great man, but he did a lot of good and he also did a lot of evil (Karl Marx, 2011: 167-168). And that «if one finds in the logical categories the essence of all things, then he imagines that he finds in the logical formula of the movement of the absolute method which not only explains all things; but also includes the movement of things."

If there is an understanding of misery in the understanding of misery, Ricoeur asked, is it possible to restore this same influence to philosophy? And he answered, «Philosophy has to turn its back 
on influentialism, and put an end to it and reduce it. This is the act of transcendent thinking that puts an end to influentialism by adopting the thing and the person as its reference.», And this is what Marx had affirmed, indicating that as long as we cling to good or bad relations; For we have a relationship of disproportion that is not a relationship of proportionality, and that who wants a correct fit by going back to past centuries and with the means of production of our time; It is utopian and reactionary together .

As for the effect of misery, it can be overlooked by imagining, which according to Al-Farabi is permissibility and forgiveness that is used in the arts in which a person needs to demonstrate complete power in the most perfection of using words, knowing that he has the ability to express something without his own wording for the slightest attachment he has to what makes The phrase about it in the second word; Or he has the ability to use the term that pertains to something on his attachment to it, even if only a little of attachment and to express himself that he has the ability to take the connections of meanings to each other, and that the metaphor has an imagination but our minds and the powers of our minds are excluded, because they are weak and far from the essence of that thing, From that we conceive of it in perfection and the perfection of existence that it is. These two plagues are each one of the other at the extreme end of existence: one of them is very perfect, and the other is very imperfect. And Al-Farabi clarified in the letter (The Views of the People of the Virtuous City and its antithesis) that if we are confused by matter, our jewels become essentially distant from the first substance, as the closer our jewels are to it, the more complete, certain and firmly our perception of it will be. This is because the closer we are to the paradox of matter, the more we conceive of it (i.e., the essence), the more complete we become. And if we completely separate the substance, then what is reasonable becomes more complete in our minds. The effect of misery dissolves with the understanding of time, so thinking about time does not become transcendent, and the question about time is by the letter (when) which "uses a question about the accident from its relative to the known limited time applicable to it and about the end of that time applicable to the end of the existence of that accident as it was Or change a body after it is in motion, static, or in still, or in motion".

Al-Farabi did not find a difference between time and space, but the characteristic of time is that it is mobile, and this is not the case in place. And the types of bodies need places, and the ratio of the exis- tence of time is that the body is excited in whatever place, then the time that applies to the thing occurs and is attributed to it for its applicability to its existence, so this ratio is similar to that ratio, I mean the ratio of the thing to its place. A certain percentage, except that it is without being where, and if it is, this percentage is later than the situation and the situation is later than where.

There is no differentiation between space and time, neither time is under place nor place is under time, and the commoners and the public are earlier in time than the common characteristics and knowledge which is the first opinion in time from the practical industries, including the making of speech and the making of jurisprudence, which Al-Farabi saw later in time than and following him). Even «suspicious philosophy or camouflaged philosophy advanced in time the certain philosophy, which is the evidence. If the religion is made human, then it is later than philosophy in time." And while misery is opposed to the idea of human fall; Looking back at time is determined by two issues, namely composition and dissolution, "and the least that falls upon composition and decomposition are two things, because one thing has neither structure nor dissolution, and it is not permissible to synthesize and analyze, except in time and time to start, and its initiation is now pure and the beginning of something other than something and the composition and analysis that takes place By two things only; but it is in the pure present, and what is to be for more than two things is in a time.

Time and place have a connection with the signs and jewels, so there is no parade without a place asking about its place where, and no essence without time asking about its time by when, "It indicates that time in which that substance was, so he made it a genus also and made it a saying when, then he found the essence also in where.".

And because movement and time have no end, the intelligible becomes in our souls an imperfect reasonable, as they were in themselves imperfect beings. Al-Farabi detailed the forces that control the human body, as the nutritional force nourishes it, and is followed by a weakening force with it that damages the body and another body takes its place, and Al-Farabi expressed this permanence by saying: "As for people with people who are newer than them, even if the first is damaged, this takes its place in order not to At all times, the presence of a person of that kind becomes vacant, either in that place or in another place. In this respect, this species of beings is perpetuated.

This understanding of permanence was expressed by Marx by means of supply and demand 
that place production and consumption against one another. Marx does not limit misery to the sufferings that accompany every birth in nature. Rather, misery [] is what makes all things that are neither bought nor bought nor sold as an object of exchange and commerce, such as virtue, love, poem, knowledge, and conscience, to be valued at some value.

5) The infinitely small / Ricoeur rejected the concept of (transcendent thinking), and he saw that the path is to move from the myths of mixture and the influence of misery in the philosophy of non-infallibility to the function of imagination in the Kantian sense that separates feeling from understanding.

Thinking is essentially divisive, sharing something else is receiving the presence of things and not assigning the meaning of things, and receiving is surrendering intuitively to their existence. Thinking is controlling this presence in a discourse that is defined by naming and linked through spoken sentences «] [, rejecting that pure imagination describing it as the third term Which is unthinkable [], and his example is the light according to Plato, who is a mediator between appearing and being able to say.

That is why Ricoeur proposed the concept of (the infinite smallness) as an alternative to transcendental thinking on the basis of the existence of a starting point which is like a monad, where the simple is what realizes the infinite intention. And between the infinite and the finite, the dialectic of name and perspective is fulfilled: "Transcendence from connotation to perception and from speech to perspective is what makes thinking possible with a viewpoint as a point of view".

O)Dorno calls this finitude (the negative dialectic), which is what the Frankfurt School means by utopianism that links philosophy to its age and is inseparable from the infinite movement and Deleuze likened the infinite to the nebula or chaos because of the infinite speed with which the form in the nebula vanishes more than it is The chaos that is characterized by it is that it is emptiness and not nothing, but it is a hypothesis that contains all possible particles and extracts all possible forms that appear to disappear head afterwards.

As for Al-Farabi, The finitude is represented by the being that has a self or has no self, and as for "the one who does not divide himself, then one of two things must be said about it: Either it exists, it does not exist, or it is said about it that the meaning of its existence is that it exists and there is no difference in it between it being said that it is Existence and that it exists and that it exists, and if it is not divided, then the meaning of its existence is that it exists in one specific meaning, or that it is said that it exists and does not exist or that it exists and does not exist in some way other than itself; rather it exists that exists in itself or exists is the very existence. And every existing image has three types, «one of which is the occurrence of the image in the sense, the other the occurrence of the image in the mind, and the third the occurrence of the image in the body." Plotinus (d.270 CE) had affirmed that unity is what is achieved in everything, while the final unity of a thing in al-Farabi's view lies in what he called (the sayings), «because each one of them gathered in it if it was signified by a wording."

\section{Conclusion}

It is no wonder that Al-Farabi's books and letters included various theories that involved a number of concepts and terms that can be recrystallized and analyzed according to the data brought by modern philosophies, including Paul Ricoeur's Philosophy of volition with its five concepts that we found manifestations evidenced in the methodologies of Farabi vision, its research data and methods of meditation In which. As for infallibility and disproportion, they are evident in Al-Farabi's quotes on wisdom and knowledge by which error is excluded and man is immune from it. As for the mixture and the mediator, they coincide with Al-Farabi>s division of things and conditions as gems and symptoms by homogeneity and incompatibility. As for clanism, it is a concept that is reflected in Al-Farabi>s study of letters as the science of proofs. As for the effect of misery, it becomes clear to Al-Farabi in the imagination by permissibility and clarification. As for the infinitesimal, its example is present in its three types. With these manifestations, the depth of the philosophical achievement left by Al-Farabi and the broadness of its physical and metaphysical horizons are confirmed for us, as well as the convergence of the natures of thought between Islamic philosophy and the philosophy of the volition on the one hand and the human philosophical thought on the other hand. And if having the volition is not always available to a person; The aspiration remains legitimate for its thought and practice, by describing the volition as the foundation of virtue and its spiritual and moral foundation. 


\section{References}

Ricoeur, Paul, (2008) Philosophy of the volition, the Wrong Man, translated by Adnan Naguib Eddin, Arab Cultural Center, Morocco, 2nd Edition.

Spinoza, (1990) A Treatise on Reforming the Mind, translated by Jalaluddin Said, Southern Publishing House, Tunis.

Al-Farabi, Abu Nasr, The Views and Contradictions of the People of the Perfect City. Two philosophical messages, which he achieved, presented to him and commented on by Dr. Jaafar Al Yassin, (1987) Al Manahil House for Publishing and Distribution, 1st Edition,

The Happiness Achieving Book.

Dr. Albert Nasri Nader, (1986) The Book of Combining the Two Wise, Beirut, 2nd Edition.

Mohsen Mahdi, Dar Al-Mashreq (1990) Book of letters, which was verified, Beirut, 2nd Edition.

Dr. Muhammad Salim Salem, (1976) A book on logic, edited by, Dar al-Kutub Press, Beirut.

Marx, Karl, (2010). The Misery of Philosophy is a response to Proudhon >s philosophy of misery, transmitted to Arabic by Muhammad Mostajir Mustafa, Dar al-Tanweer, Beirut, 4th Edition.

Hegel, Frederick, (2006) The Phenomenology of the Soul, translated and presented by Dr. Naji Al-Aounli, The Arab Organization for Translation, Beirut, 1st Edition. 